\title{
Isolation and Properties of a Denitrifying Bacterium Related to Pseudomonas lemoignei
}

\author{
F. PICHINOTY, ${ }^{1}$ M. MANDEL, ${ }^{2}$ B. GREENWAY,' ${ }^{2}$ AND J.-L. GARCIA ${ }^{3}$ \\ Laboratoire de Biochimie Végétale, UER Scientifique de Luminy, Marseille, France; 'The University of \\ Texas System Cancer Center, M. D. Anderson Hospital and Tumor Institute, Houston, Texas $77030 ;{ }^{2}$ and \\ Laboratoire de Microbiologie, O.R.S.T.O.M., Dakar, Senegal ${ }^{3}$
}

A previously undescribed denitrifying bacterium was isolated from soil. The cells are small, gram negative, slightly curved rods, asporogenous, and nonmotile. Motile clones, however, have been isolated from the nonmotile parent: these cells possess a single polar flagellum. The organism shows no fermenting activity and grows only in the presence of one of the following electron acceptors: $\mathrm{NO}_{3}{ }^{-}$, $\mathrm{NO}_{2}{ }^{-}, \mathrm{N}_{2} \mathrm{O}, \mathrm{S}_{4} \mathrm{O}_{6}{ }^{2-}$, and $\mathrm{O}_{2}$. It gives a positive oxidase test and has a cytochrome $c$ and catalase. It requires no growth factors, is a chemoorganotroph, and uses only some alcohols and organic acids as carbon and energy supply. Poly- $\beta$ hydroxybutyrate is synthesized. 'The deoxyribonucleic acid base composition is $62.2 \mathrm{~mol} \%$ guanine plus cytosine. The bacterium bears greatest resemblance to Pseudomonas lemoignei.

In a previous article we drew attention to the advantage of using nitrous oxide as a respiratory electron acceptor for the isolation of denitrifying bacteria by enrichment culture (7). In this manner, we have isolated an organism that is clearly different from the known denitrifiers of the genus $P$ seudomonas. This paper describes the bacterium.

\section{MATERIALS AND METHODS}

Isolation procedure. The mineral basal medium used for all media contained the following (per liter of distilled water): $\mathrm{Na}_{2} \mathrm{HPO}_{4} \cdot 12 \mathrm{H}_{2} \mathrm{O}, 3.575 \mathrm{~g} ; \mathrm{KH}_{2} \mathrm{PO}_{4}$, $0.98 \mathrm{~g} ; \mathrm{MgSO}_{4} \cdot 7 \mathrm{H}_{2} \mathrm{O}, 0.03 \mathrm{~g} ; \mathrm{NH}_{4} \mathrm{Cl}, 0.5 \mathrm{~g}$; solution containing calcium and various heavy metals chelated with EDTA (ethylenediaminetetraacetic acid, disodium salt dihydrate, $50.0 \mathrm{~g} ; \mathrm{ZnSO}_{4} \cdot 7 \mathrm{H}_{2} \mathrm{O}, 2.2 \mathrm{~g} ; \mathrm{CaCl}_{2}$, $5.54 \mathrm{~g} ; \mathrm{MnCl}_{2} \cdot 4 \mathrm{H}_{2} \mathrm{O}, 5.06 \mathrm{~g} ; \mathrm{FeSO}_{4} \cdot 7 \mathrm{H}_{2} \mathrm{O}, 4.79 \mathrm{~g}$; $\mathrm{NH}_{4} \mathrm{Mo}_{7} \mathrm{O}_{24} \cdot 4 \mathrm{H}_{2} \mathrm{O}, 1.1 \mathrm{~g} ; \mathrm{CuSO}_{4} \cdot 5 \mathrm{H}_{2} \mathrm{O}, 1.57 \mathrm{~g} ;$ $\mathrm{CoCl}_{2} \cdot 6 \mathrm{H}_{2} \mathrm{O}, 1.6 \mathrm{~g} ; \mathrm{H}_{3} \mathrm{BO}_{3}, 0.05 \mathrm{~g}$; distilled water, 1,000 $\mathrm{ml}$; adjusted to $\mathrm{pH} 6.0$ with $\mathrm{KOH}$ ), $0.2 \mathrm{ml} ; \mathrm{pH} 7.0$.

An enrichment culture was made in liquid medium containing $4.0 \mathrm{~g}$ of sodium succinate per liter under an atmosphere of pure $\mathrm{N}_{2} \mathrm{O}$. The inoculum was a sample of sulfide-containing mud from an anaerobic edge of a lagoon near the town of Berre (Etang de Berre), France. This body of water communicates with the sea. Primary cultures were kept at $32^{\circ} \mathrm{C}$ for a week and then serially transferred a number of times. Colonies of bacteria were isolated after transfer to solid medium (same medium containing $1.4 \%$ agar) and aerobic incubation at $32^{\circ} \mathrm{C}$ for 3 days. Clones were purified by several successive streakings and verified as pure when colonies of only one type were produced. The bacterium thus isolated can be maintained on nutrient agar but must be transferred every week.

Although several more enrichment cultures were made under the same conditions starting with various garden soil and sulfide-containing mud samples, we were not able to reisolate this bacterium.

Identification methods. The methods used in characterization were described previously $(7,9)$. Poly$\beta$-hydroxybutyrate was identified by Sudan black staining and by extraction in hot $\mathrm{CHCl}_{3}$. The extract was converted to crotonic acid by heating at $100^{\circ} \mathrm{C}$ in the presence of concentrated $\mathrm{H}_{2} \mathrm{SO}_{4}$ (4). Tetrathionate reduction was demonstrated by iodometric assay of the thiosulfate formed in anaerobic cultures.

Broth-grown cells $\left(25^{\circ} \mathrm{C}\right)$ were absorbed on 300 mesh, Formvar-coated copper grids for $5 \mathrm{~min}$ at room temperature and stained with $2 \%$ sodium phosphotungstate at $\mathrm{pH}$ 7.5. Grids were examined in a Siemens electron microscope (Elmiskop IA) equipped with a $50-\mathrm{nm}$ objective aperture and operated at $80 \mathrm{kV}$.

\section{RESULTS}

Morphology. Colonies are convex, translucent, circular with entire margins, slightly yellow, and do not exceed $3 \mathrm{~mm}$ in diameter on nutrient agar. They are neither coherent nor adherent to agar.

The short and slightly curved rods have rounded ends ( 1.2 to $2.4 \mu \mathrm{m}$ by 0.6 to $0.8 \mu \mathrm{m}$ ) and multiply by binary fission. The original isolate was nonmotile, but motile clones have been isolated from the periphery of growth in semisolid media ( $4.0 \mathrm{~g}$ of agar per liter). These cells possess a single polar flagellum and are otherwise identical to the nonmotile parent. Cells are gram negative and form no endospores. Capsules were not observed. Examination of cells of the motile variant by electron microscopy confirms the presence of a polar flagellum and shows the absence of pili (Fig. 1). The clear zones probably 


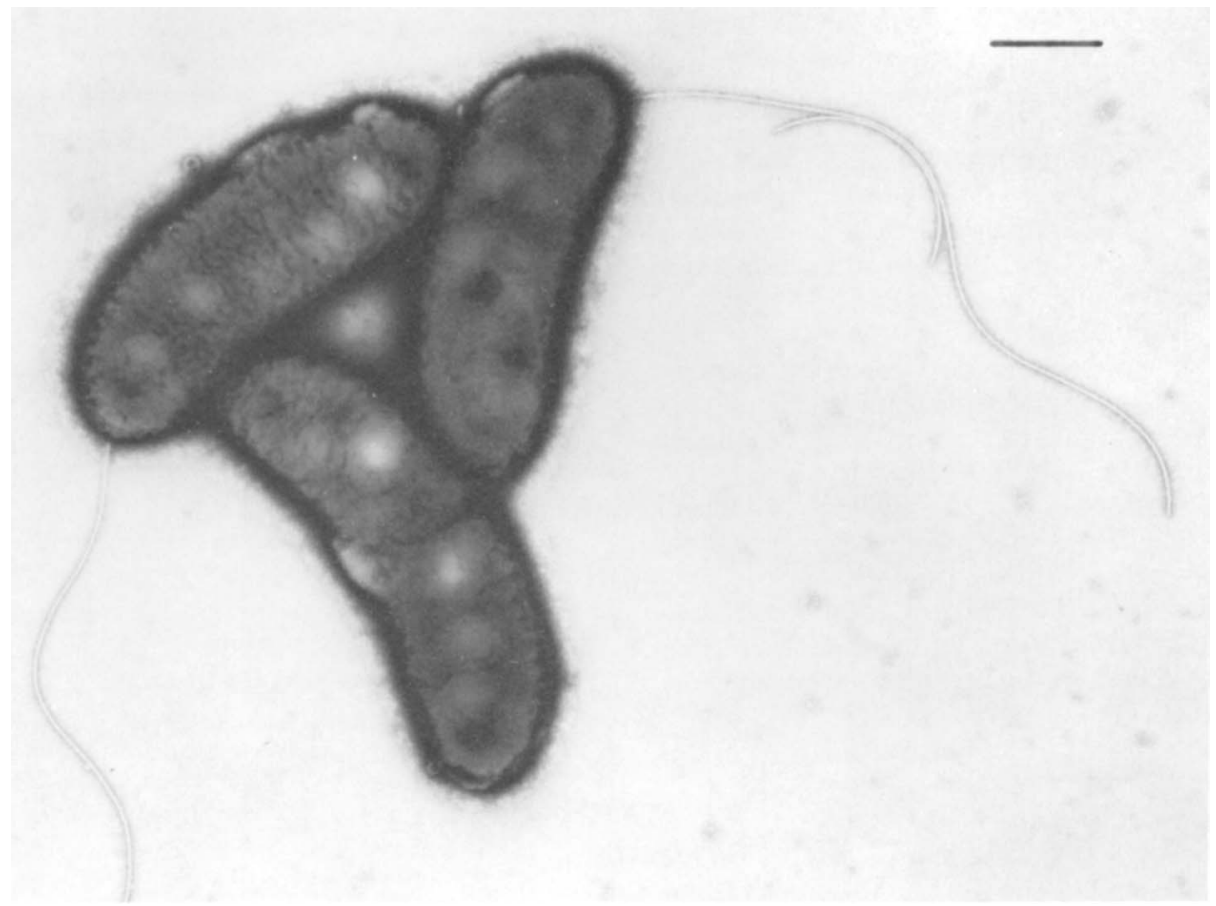

FIG. 1. Electron micrograph of negatively stained cells of a motile clone. Bar represents $0.5 \mu m$.

represent deposits of poly- $\beta$-hydroxybutyrate because this compound is very electron transparent.

Cultural and physiological characters. The organism is a chemoorganotroph that does not grow in liquid mineral media under atmospheres containing $\mathrm{H}_{2}, \mathrm{O}_{2}$ (or $\mathrm{N}_{2} \mathrm{O}$ ), and $\mathrm{CO}_{2}$, and does not require any growth factor. Metabolism is respiratory; using $\mathrm{O}_{2}, \mathrm{NO}_{3}{ }^{-}, \mathrm{NO}_{2}{ }^{-}, \mathrm{N}_{2} \mathrm{O}$, or $\mathrm{S}_{4} \mathrm{O}_{6}{ }^{2-}$ as substrates. Fermentative activity is completely lacking. The bacterium reduces nitrate to nitrite with feeble production of gas, but it denitrifies nitrous oxide vigorously. It grows in nutrient broth (Difco) at $\mathrm{pH} \mathrm{9.0,} \mathrm{but}$ not in peptone water containing $3 \% \mathrm{NaCl}$. It does not grow at $4^{\circ} \mathrm{C}$ nor at $40^{\circ} \mathrm{C}$. In nutrient broth (Difco), growth is flocculent and a pellicle is formed. No brown or black pigment is produced on nutrient agar (Difco) containing 10.0 $\mathrm{g}$ of tyrosine per liter.

The bacterium synthesizes poly- $\beta$-hydroxybutyrate when grown in medium containing DL3 -hydroxybutyrate. Purified poly- $\beta$-hydroxybutyrate (from Bacillus megaterium) is neither hydrolyzed nor assimilated. Metachromatic granules are not found within cells grown on nutrient agar.

The following compounds are utilized as sources of carbon and energy: ethanol, propanol, butanol, 1,2-propanediol, acetate, propionate, butyrate, isovalerate, succinate, fumarate, L-lactate, D-lactate, DL-3-hydroxybutyrate, L-malate, D-malate, pyruvate, $\alpha$-ketoglutarate. The following compounds are not used as sources of carbon and energy: 2,3-butanediol, 1,2-ethanediol, glycerol, isobutanol, methanol, isobutyrate, valerate, caproate, pelargonate, caprate, malonate, glutarate, adipate, pimelate, suberate, sebacate, glycolate, citrate, DL-isocitrate, tartronate, $\beta$-hydroxy- $\beta$-methylglutarate, $d$-tartrate, $l$-tartrate, meso-tartrate, mucate, azelaidate, levulinate, maleate, itaconate, trans-aconitate, cis-aconitate, mesaconate, citraconate, crotonate, geraniol. None of the carbohydrates, amino acids, aromatic acids, nor amines tested (9) can serve as carbon and energy sources.

The organism is oxidase and catalase positive. It contains cytochrome $c$ whose reduced form has major peaks of absorption at $551.5 \mathrm{~nm}(\alpha)$ and at $522 \mathrm{~nm}(\beta)$. Neither pyocyanin nor fluorescent pigments are produced in the King $\mathrm{A}$ or King B media, respectively. Gelatin is not liquefied, and starch, Tween 80, and lecithin are not hydrolyzed. Urease is not produced, nor is indole. Hydrogenase is produced in anaerobiosis in a complex medium containing succinate and yeast extract under an atmosphere of $\mathrm{H}_{2}$ and $\mathrm{N}_{2} \mathrm{O}$. L-Phenylalanine deaminase is not produced nor is constitutive arginine dihydrolase. Nitrogen is not fixed. Nitrate is assimilated. Ni- 
trate reductase $\mathrm{A}$ is demonstrable in anaerobic culture with $\mathrm{NO}_{3}^{-}$; nitrate reductase $\mathrm{B}$ is demonstrable in aerobic culture grown in the absence of $\mathrm{NO}_{3}{ }^{-}(6)$. Extracts of cells cultivated anaerobically in the presence of $\mathrm{NO}_{3}{ }^{-}, \mathrm{NO}_{2}^{-}$, or $\mathrm{N}_{2} \mathrm{O}$ yield extremely little or no tetramethyl $-p$ phenylenediamine-nitrite reductase activity. Tetrathionate reductase is produced in anaerobiosis in a medium containing $\mathrm{S}_{4} \mathrm{O}_{6}{ }^{2-}$.

Growth and denitrification of $\mathrm{N}_{2} \mathrm{O}$ are obtained in complex media with yeast extract or in minimal media containing acetate, butyrate, succinate, DL-lactate, or L-malate. The dinitrogen produced in stoichiometric amounts from the reduction of $\mathrm{N}_{2} \mathrm{O}$ in the presence of succinate by cell suspensions has been measured and identified by gas chromatography (3).

DNA base composition. The deoxyribonucleic acid (DNA) has a buoyant density in $\mathrm{CsCl}$ of $1.721 \mathrm{~g} / \mathrm{cm}^{3}$, indicating a base composition of $62.2 \mathrm{~mol} \%$ guanine plus cytosine $(\mathrm{G}+\mathrm{C})(5,8)$.

Taxonomy. The bacterium clearly is a member of the genus Pseudomonas. The species known to denitrify are $P$. aeruginosa, $P$. fluorescens, $P$. stutzeri (including P. stanieri), P. mendocina, $P$. pseudomallei, $P$. mallei, $P$. solanacearum, $P$. caryophylli, and P. pickettii. All of these are nutritionally omnivorous and assimilate a broad range of carbohydrates and amino acids $(2,9)$. Physiologically, the bacterium we have encountered and described bears greatest resemblance to $P$. lemoignei. The latter assimilates only acetate, butyrate, valerate, pyruvate, succinate, and DL-3-hydroxybutyrate, and accumulates poly- $\beta$-hydroxybutyrate as a reserve substance. It also is characterized by equally small colonies. However, $P$. lemoignei differs in growing at $41^{\circ} \mathrm{C}$, in producing colonies that are very coherent and adherent to agar, in not assimilating DL-lactate, propionate, L-malate, and $\alpha$ ketoglutarate, in failing to denitrify, and in being able to hydrolyze extracellular poly- $\beta$-hydroxybutyrate. Furthermore, its colonies and surrounding media turn brown or black when it is grown on complex media or media containing tyrosine and a suitable carbon source, and the $\mathrm{G}+\mathrm{C}$ content of its DNA is $58.2 \mathrm{~mol} \%$ (1).

\section{DISCUSSION}

We do not know whether the use of tetrathionate as a respiratory electron acceptor is specific to the bacterium described because the pseudomonads were never examined for this character.
Is this organism a new species or is it a denitrifying variety of $P$. lemoignei? Only by studying new strains can we determine its taxonomic position. Unfortunately there are serious difficulties in isolating such strains because the culture conditions used during enrichment are not selective. They allow the growth of other denitrifying bacteria such as $P$. stutzeri and Alcaligenes denitrificans. It should be remembered that only one strain of $P$. lemoignei has been isolated and described (1).

We have deposited the holotype in the collection of the Pasteur Institute (number CIP 30175).

\section{ACKNOWLEDGMENTS}

We thank C. Gorman and H. D. Mayor for the preparation of electron micrographs.

\section{REPRINT REQUESTS}

Address reprint requests to: Dr. Francis Pichinoty, Laboratoire de Biochimie Végétale, UER Scientifique de Luminy, 70 route Léon Lachamp, 13288 Marseille Cédex 2, France.

\section{LITERATURE CITED}

1. Delafield, F. P., M. Doudoroff, N. J. Palleroni, C. J. Lusty, and R. Contopoulos. 1965. Decomposition of poly- $\beta$-hydroxybutyrate by pseudomonads. J. Bacteriol. 90:1455-1466.

2. Doudoroff, M., and N. J. Palleroni. 1974. Genus I. Pseudomonas Migula 1894, 237 Nom. cons. Opin. 5, Jud. Comm. 1952, 121, p. 217-243. In R. E. Buchanan and N. E. Gibbons (ed.), Bergey's manual of determinative bacteriology, 8 th ed., The Williams \& Wilkins Co., Baltimore.

3. Garcia, J.-L. 1974. Réduction de l'oxyde nitreux dans les sols de rizières du Sénégal: mesure de l'activité dénitrifiante. Soil Biol. Biochem. 6:79-84.

4. Law, J. H., and R. A. Slepecky. 1961. Assay of poly- $\beta$ hydroxybutyric acid. J. Bacteriol. 82:33-36.

5. Mandel, M., C. L. Schildkraut, and J. Marmur. 1968. Use of $\mathrm{CsCl}$ density gradient analysis for determining the guanine plus cytosine content of DNA, p. 184-195. In L. Grossman and K. Moldave (ed.), Methods in enzymology, vol. 12B. Academic Press Inc., New York.

6. Pichinoty, F., and M. Piéchaud. 1968. Recherche des nitrate-réductases bactériennes A et B: méthodes. Ann. Inst. Pasteur 114:77-98.

7. Pichinoty, F., J. Bigliardi-Rouvier, G. Méténier, M. Mandel, B. Greenway, and J.-L. Garcia. 1976. The isolation and properties of a denitrifying bacterium of the genus Flavobacterium. Antonie van Leeuwenhoek J. Microbiol. Serol. 42:349-354.

8. Schildkraut, C. L., J. Marmur, and P. Doty. 1962. Determination of the base composition of deoxyribonucleic acid from its buoyant density in $\mathrm{CsCl}$. J. Mol. Biol. 4:430-433.

9. Stanier, R. Y, N. J. Palleroni, and M. Doudoroff. 1966. The aerobic pseudomonads: a taxonomic study. J. Gen. Microbiol. 43:159-271. 